\title{
Nitrate supplementation in thoroughbred racehorses: Addition of beetroot juice to the equine diet and effects on the gut metabolome
}

\author{
RH Waring ${ }^{1 *}$, JO Hunter ${ }^{2}$, C Turner ${ }^{3}, \mathrm{C}$ Batty $^{3}$ and PHL Ramzan ${ }^{4}$ \\ ${ }^{1} \mathrm{DSc}$, School of Biosciences, University of Birmingham, Birmingham B15 2TT, UK \\ ${ }^{2}$ FRCP, Gastroenterology Research Unit, Addenbrooke's Hospital, Cambridge CB2 0QQ, UK \\ ${ }^{3} \mathrm{PhD}$ School of Life, Health and Chemical Sciences, The Open University, Milton Keynes MK7 6AA, UK \\ ${ }^{4}$ MRCVS Rossdales Veterinary Practice, Newmarket, Suffolk CB8 7NN, UK
}

\begin{abstract}
Beetroot juice (BJ), a source of nitrate, was added to the diet of thoroughbred racehorses for a four-week period. Analysis of nitrate/nitrite in plasma showed no significant differences between control and dosed groups. SIFT/MS (selected ion-flow tube/mass spectrometry) was used to analyse the faecal metabolome. The levels and types of volatile organic compounds (VOCs) were compared using headspace sampling of faeces from control and beetroot-supplemented equines, However, there were no significant differences apart from raised levels of acetonitrile in samples from the animals dosed with BJ. The conclusion was that racehorses appear not to have nitrate transporters and that addition of $\mathrm{BJ}$ to equine diets would not improve performance.
\end{abstract}

\section{Introduction}

Beetroot juice $(\mathrm{BJ})$ is a rich source of nitrate $\left(\mathrm{NO}_{3}^{+}\right)$and is frequently taken by athletes attempting to improve their performance. In humans, nitrate is reduced to nitrite $\left(\mathrm{NO}_{2}^{-}\right)$, nitric oxide $(\mathrm{NO})$ and ammonia by salivary and enteric bacteria [1] and by several enzymes and proteins including xanthine oxidase, deoxyhaemoglobin and myoglobin [2]. Salivary-derived nitrite is partly reduced to NO in the acidic stomach but a high proportion enters the systemic circulation before metabolism to NO in blood and tissues. NO has many effects including vasodilation, reduction in blood pressure and reduction in oxidative stress [3]. It also mediates glucose uptake in the intestines and skeletal muscle [4] and could therefore potentially increase the energy supply required for high-speed exertion. Although there have been many reports of the use of $\mathrm{BJ}$ in human athletes, its effects are variable since not all athletes appear to benefit. There has so far been no corresponding data on the effects of $\mathrm{BJ}$ in racehorses, the corresponding equine equivalent. It is therefore unclear whether horses' performance would improve with nitrate supplementation.

\section{Experimental methods}

\section{Dose administration}

Racehorses (20), colts and geldings in full training, were divided into two equal groups. Each horse was stabled at the same premises and was under the management of the same trainer. All were in active flat race training. They were free from concurrent medication and were fed a standard diet containing oats and hay with supplements (Table 1). Although human competitors take $500 \mathrm{ml} \mathrm{BJ}$ before a race, the equivalent dose in equines would be $\sim 4$ litres which would be impractical before a race. Group A therefore received beetroot solids/beetroot juice with a malt supplement to mask the taste $(300 \mathrm{ml} /$ day, ERME, supplied by
Table 1. Total daily intake for all horses

\begin{tabular}{|c|c|}
\hline Oats + balancer & $5.25 \mathrm{~kg}$ \\
\hline 'Outshine' (Bailey's Horse Feeds) & $520 \mathrm{~g}$ \\
\hline Linseed oil & $220 \mathrm{ml}$ \\
\hline Salt & $51 \mathrm{~g}$ \\
\hline Electrolytes & $132 \mathrm{~g}$ \\
\hline Timothy hay & $4.1 \mathrm{~kg}$ \\
\hline Alfalfa hay & $0.6 \mathrm{~kg}$ \\
\hline
\end{tabular}

Muntons of Stowmarket). This provided a final concentration of $60 \%$ solids while the controls (group B) received ERME alone $(300 \mathrm{ml} /$ day, $60 \%$ solids). Dosing was continuous over a four-week period to provide a steady input of nitrate.

\section{Determination of nitrite/nitrate}

Blood samples for analysis of nitrate and nitrite were taken at the start of the study then at 1,2 and 4 weeks. Samples were taken by courier to the analysing laboratory, Sequani Laboratories (Ledbury). Initially, nitrite was determined using the Griess reaction [5] where there is a two-stage diazotization step. The acidified $\mathrm{NO}_{2}^{+}$ion produces a nitrosating agent which reacts with sulfanilic acid to form a diazonium ion which is then coupled to $\mathrm{N}$-(1-naphthyl)-ethylenediamine. The azo derivative produced absorbs light at $540-570 \mathrm{~nm}$ and the assays

${ }^{\star}$ Correspondence to: Rosemary Waring, School of Biosciences, University of Birmingham, Birmingham, B15 2TT, UK, Tel. 0121-4477881, E-mail: r.h.waring@bham.ac.uk

Key words: beetroot, faecal metabolome, nitrate, nitrite, racehorses

Received: January 22, 2019; Accepted: February 07, 2019; Published: February 11,2019 
were therefore read on a microplate reader set at $540 \mathrm{~nm}$. The limit of detection for this assay was $12.62 \mu \mathrm{mol} /$ litre. Nitrate was then reduced to nitrite using NADH and nitrate reductase and the Griess reaction was again performed; nitrate was determined by subtracting endogenous nitrite from the total nitrite value. The limit of detection for the assay was $23.09 \mu \mathrm{mol} / \mathrm{litre}$.

\section{Analysis of faecal volatile organic compounds}

A sample of faeces was taken from each animal at the start of the study and again after 4 weeks. This was stored frozen until the whole collection was transferred to the Open University (Milton Keynes) for volatile organic compounds (VOCs) analysis by selected ion-flow tube mass spectrometry (SIFT/MS). Faecal samples were taken from the $-80^{\circ} \mathrm{C}$ freezer and thoroughly defrosted. Exactly $5 \mathrm{~g}$ of each sample was weighed out and placed into a sample bag constructed from Nalophan tubing. The bag was filled with zero grade (hydrocarbon free) air before being sealed with a Swagelok fitting, then placed in the incubator at $40^{\circ} \mathrm{C}$ for 45 minutes, to increase compound volatilization. After incubation, samples were then attached to the SIFT-MS via the heated sampling capillary. SIFT-MS is a real-time trace gas analyser where selected precursor ions $\left(\mathrm{H}_{3} \mathrm{O}+, \mathrm{NO}+\right.$ or $\mathrm{O}_{2}+$, generated in an air/water mixture via a microwave discharge and then selected via an upstream quadrupole mass filter) are injected into helium carrier gas, and passed along a flow tube into which the sample is introduced via the heated capillary. The precursor ions react with the sample compounds and the resulting product ions are then separated in a downstream quadrupole mass filter before being detected and counted [6].

\section{Results}

\section{Nitrate/Nitrite}

The results were analysed using GraphPad Quick Calcs t-test. At the start of the study the mean plasma concentration of nitrate was slightly higher in the control group than in the test $(43.9+/-7.8 \mathrm{v}$. $35.2+/-17.8 \mu \mathrm{mol} /$ litre) but this was not significant (Tables 2 and 3 ). During the trial, the level rose slightly in test group A to $48.3+/-20.1$ $\mu \mathrm{mol} /$ litre although again this was not significant. However, the mean level in control group B fell to $29.6+/-18.0 \mu \mathrm{mol} /$ litre (not significantly different from the starting level) and the significance between the 2 groups after 4 weeks was $\mathrm{p}=0.04$. In all cases, the endogenous nitrite level was at the limit of detection $(<12.62 \mu \mathrm{mol} /$ litre $)$.

\section{Volatile organic compounds}

The results from the chemical analysis of the faecal metabolome were analysed using Mann Whitney U-test Calculator (Social Science Statistics). The low levels of faecal acetate $(61+/-140 \mathrm{v} .141+/-184 \mathrm{ppb})$ were unchanged by the treatment with BJ $(61+/-140 \mathrm{v} .137+/-195 \mathrm{ppb})$ as were the levels of propionate and butyrate. There was no difference in the two groups and no change after treatment in levels of formaldehyde, acetaldehyde, methanol, ethanol, propanol, butanol, phenol, methyl phenol, ethyl phenol, hydrogen sulphide, hydrogen cyanide, keto acids, dimethyl sulphide and dimethyl disulphide, benzene or indole. However, the mean level of ammonia was significantly greater in control group B before treatment $(106.4+/-93$ v. $347+/-192.3$ ppb, $\mathrm{p}=0.002)$ and this was unchanged after treatment $(129.9+/-80.2 \mathrm{v}$. $248.6+/-346.1 \mathrm{ppb}$ ). The only parameter to change significantly in test

Table 2. Nitrate levels ( $\mu \mathrm{mol} /$ litre) in test horses with beetroot juice supplement

\begin{tabular}{|c|c|c|c|c|}
\hline Test Horses & Study start & Week 1 & Week 2 & Week 4 \\
\hline A1 & 41.55 & 53.60 & 33.53 & 44.34 \\
\hline A2 & 36.53 & 37.63 & 24.68 & 40.77 \\
\hline $\mathrm{A} 3$ & 54.21 & 50.06 & 22.72 & 33.69 \\
\hline A4 & 43.57 & 42.64 & 55.59 & 47.29 \\
\hline A5 & 38.43 & 76.91 & 57.44 & 51.75 \\
\hline A6 & 51.18 & 76.01 & 53.57 & 43.49 \\
\hline A7 & 57.91 & 57.31 & 31.96 & 62.07 \\
\hline A8 & 35.22 & 46.04 & 26.29 & 54.32 \\
\hline A9 & 41.64 & 38.67 & 31.50 & 13.37 \\
\hline A 10 & 39.16 & 51.48 & 104.31 & 91.48 \\
\hline Mean & 43.94 & 53.04 & 44.16 & 48.26 \\
\hline SD & 7.81 & 13.86 & 24.93 & 20.09 \\
\hline
\end{tabular}

Table 3. Nitrate levels ( $\mu \mathrm{mol} / \mathrm{litre})$ in control horses

\begin{tabular}{|c|c|c|c|c|}
\hline Control horses & Study start & Week 1 & Week 2 & Week 4 \\
\hline B1 & 40.45 & 49.29 & 23.37 & 40.30 \\
\hline B2 & 16.87 & 37.16 & 16.88 & 61.09 \\
\hline B3 & 16.87 & 35.11 & 39.51 & 16.25 \\
\hline B4 & 43.72 & 53.90 & 48.21 & 16.95 \\
\hline B5 & 19.11 & 46.16 & 10.47 & 12.74 \\
\hline B6 & 34.76 & 84.02 & 24.38 & 23.09 \\
\hline B7 & 44.09 & 44.70 & 37.38 & 21.15 \\
\hline B8 & 15.68 & 20.81 & 81.80 & 10.47 \\
\hline B9 & 68.18 & 61.29 & 85.27 & 53.80 \\
\hline B10 & 52.06 & 88.87 & 43.00 & 40.49 \\
\hline Mean & 35.18 & 52.13 & 41.03 & 29.63 \\
\hline $\mathrm{SD}$ & 17.84 & 21.21 & 25.38 & 17.99 \\
\hline
\end{tabular}


group A was acetonitrile $\left(\mathrm{CH}_{3} \mathrm{CN}\right)$ which rose from $9.4+/-26$ to 46.3 $+/-38 \mathrm{ppb}, \mathrm{p}<0.05$.

No effect was noticed on the animals' performance.

\section{Discussion}

Several studies in human athletes have suggested that supplementation with $\mathrm{BJ} /$ nitrate can give equivocal results; a review of the field found contradictory data and the physiological effects seem variable. There were no individual or combined effects of caffeine and beetroot juice in one trial [7]. Nitrate-rich beetroot juice elevated plasma nitrite concentrations in a small randomised trial but did not alter plasma glucose or hepatic blood flow [4] while Shannon et al, who also found that beetroot juice supplementation significantly elevated plasma nitrite, showed an enhancement of short but not long duration time-trial performances [8]. Double-blind crossover studies suggested that BJ supplementation could either enhance brief high-intensity action in cyclists [9] or have relatively little effect in trained athletes [10].

In human subjects, it is clear that ingestion of BJ can increase urinary nitrate, nitrite and NO metabolites [11] and conversion of nitrate to other nitrogen-containing metabolites is commonly reported. However, in the equine equivalent of trained athletes, supplementation with BJ gave a non-significant rise in plasma nitrate and no increase in plasma nitrite. As the horse stomach is less acid than that in humans, it seems unlikely that there is much conversion of any nitrite which may be formed to NO. These results suggest that racehorses do not have nitrate-transporter systems. Although such proteins have been extensively studied in plants and bacteria, there is little known about the equivalents in mammals. Pigs and humans are omnivorous and so may include nitrate-rich foodstuffs such as spinach, beetroot and lettuce in their diet. They both have the protein sialin as an electrogenic $2 \mathrm{NO}_{3}^{-} / \mathrm{H}^{+}$transporter in the plasma membrane of salivary acinar cells. They also have oral bacterial species at the posterior part of the tongue which catalyse the conversion of nitrate to nitrite by nitrate reductase enzymes [12,13]. However, horses have evolved to eat mainly grass which contains little or no nitrate and so do not appear to have the related transporters or reductase enzymes.

There was no effect on the gut microbiome, since faecal metabolites were unchanged in the two groups, apart from raised acetonitrile levels in the test group. This was presumably derived from reductive metabolism of nitrate by gut bacteria, clearly showing that nitrogen - containing compounds from the beetroot diet had entered the digestive tract. The malt extract ERME is known to alter the gut microbiome [6] but since both groups of horses were fed the same amount any effects were compensated for. Dietary components such as vegetables and resistant starch can alter the profile of the gut bacteria in human populations [14,15]. However, although carbohydrate polymers form $\sim 70 \%$ of beetroot dry matter, its long-term ingestion appears not to affect the horse gut microbiome since the metabolome was almost unchanged.

\section{Conclusion}

The horses fed BJ showed no changes in nitrate/nitrite levels, faecal metabolome or performance. The conclusion must be that supplementation with BJ has no effect on racehorses, despite some commercial products marketed for equine nutrition which include it in the list of ingredients. As racehorses are a relatively inbred strain, it is possible that BJ might be effective in ordinary equines if they possessed the required nitrate transporter proteins/reductase enzymes.

\section{Ethics}

The horses were all cared for by a qualified vet who supervised the changes in diet and the blood sampling. Several products on the equine market contain beetroot although there is no scientific evidence that this improves performance. The project was undertaken because the trainer wished to know whether the horses would respond positively to beetroot as a dietary supplement since this had been reported in human athletes. The vet was concerned to know whether beetroot would in fact be beneficial and could therefore be recommended. This pilot project was therefore undertaken to provide the required evidence.

\section{Financial support}

None

\section{Conflicts of interest}

The authors declare no conflicts of interest.

\section{Disclosure}

$\mathrm{JOH}-$ responsible for the conception and design of the experiments

RHW- responsible for initial idea, the drafting of the article and interpretation of results

CT- responsible for data analysis and interpretation of results

CB- responsible for data acquisition and analysis

\section{References}

1. Tiso M, Schechter AN (2015) Nitrate reduction to nitrite, nitric oxide and ammonia by gut bacteria under physiological conditions. PLoS One 10: e 0127490. [Crossref]

2. Lundberg JO, Weitzberg E, Gladwin MT (2008) The nitrate-nitrite-nitric oxide pathway in physiology and therapeutics. Nat Rev Drug Discov 7: 156-167. [Crossref]

3. Lundberg JO1 (2012) Nitrate transport in salivary glands with implications for NO homeostasis. Proc Natl Acad Sci U S A 109: 13144-13145. [Crossref]

4. Shepherd AI, Wilkerson DP, Fulford J, Winyard PG, Benjamin N, et al. (2016) Effect of nitrate supplementation on hepatic blood flow and glucose homeostasis: a double-blind, placebo-controlled randomised control trial. Am J Physiol Gastrointest Liver Physiol 311: G356-G364. [Crossref]

5. Giustarini D, Rossi R, Milzani A, Dalle-Donne I (2008) Nitrite and nitrate measurement by Griess reagent in human plasma: evaluation of interferences and standardization. Methods Enzymol 440: 361-380. [Crossref]

6. Proudman CJ, Hunter JO, Darby AC, Escalona EE, Batty C, et al. (2015) Characterisation of the faecal metabolome and microbiome of Thoroughbred racehorses. Equine Vet $J$ 47: 580-586. [Crossref]

7. Oskarsson J, McGawley K (2018) No individual or combined effects of caffeine and beetroot-juice supplementation during submaximal or maximal running. Appl Physiol Nutr Metab 43: 697-703. [Crossref]

8. Shannon OM, Barlow MJ, Duckworth L, Williams E, Wort G, et al. (2017) Nitrate supplementation enhances short but not longer duration running time-trial performance. European Journal of Applied Physiology 117: 775-785.

9. Rimer EG, Peterson LR, Coggan AR, Martin JC (2016) Increase in maximal cycling power with acute dietary nitrate supplementation. Int $J$ Sports Physiol Perform 11: 715-720. [Crossref]

10. Balsalobre-Fernández C, Romero-Moraleda B, Cupeiro R, Peinado AB, Butragueño J, et al. (2018) The effects of beetroot juice supplementation on exercise, economy rating of perceived exertion and running mechanisms in elite distance runners: a doubleblinded randomised study. PLOS ONE 13: e0200517. [Crossref]

11. Baião Ddos S, Conte-Junior CA, Paschoalin VM, Alvares TS (2016) Beetroot juice increase nitric oxide metabolites in both men and women regardless of body mass. Int J Food Sci Nutr 67: 40-46. [Crossref] 
Waring RH (2019) Nitrate supplementation in thoroughbred racehorses: Addition of beetroot juice to the equine diet and effects on the gut metabolome

12. Qin L, Liu X, Sun Q, Fan Z, Xia D, et al. (2012) Sialin (SLC17A5) Functions as a nitrate transporter in the plasma membrane. Proceedings of the National Academy of Sciences USA 109: 13434-13439.

13. Qu XM, Wu ZF, Pang BX, Jin LY, Qin LZ, et al. (2016) From nitrate to nitric oxide: The role of salivary glands and oral bacteria. $J$ Dent Res 95: 1452-1456. [Crossref]
14. De Filippis F, Pellegrini N, Vannini L, Jeffery IB, et al. (2016) High-level adherence to a Mediterranean diet beneficially impacts the gut microbiota and associated metabolome. Gut 65: 1812-1821. [Crossref]

15. Maier TV, Lucio M, Lee LH, VerBerkmoes NC, Brislawn CJ, et al. (2017) Impact of Dietary Resistant Starch on the Human Gut Microbiome, Metaproteome, and Metabolome. MBio 8. [Crossref]

Copyright: $@ 2019$ Waring RH. This is an open-access article distributed under the terms of the Creative Commons Attribution License, which permits unrestricted use, distribution, and reproduction in any medium, provided the original author and source are credited. 